Review Article 2019

\title{
Origin and Evolution of the Vindhyan Basin: A Geochemical Perspective
}

\author{
PALLABI BASU and RAMANANDA CHAKRABARTI* \\ Centre for Earth Sciences, Indian Institute of Science, Bangalore 560 012, India
}

(Received on 10 September 2019; Accepted on 25 September 2019)

\begin{abstract}
The Indian Peninsula hosts several Proterozoic sedimentary basins, popularly known as the Purana basins. The Vindhyan Basin of central India, comprising $\sim 5 \mathrm{~km}$ thick sediment pile, is the largest among the Purana basins. The sedimentary units comprise mostly of undeformed and unmetamorphosed siliciclastic and carbonate rocks. With an initiation age of late Paleoproterozoic, the sedimentation in the Vindhyan Basin continued up to late Mesoproterozoic to early Neoproterozoic. The undeformed and unmetamorphosed nature of the sediments with a prolonged extent of sedimentation makes the Vindhyan Basin an excellent archive for geochemical and isotopic studies. The present study provides an overview of the existing geochemical, geochronological and isotopic data for the sedimentary and volcanic rocks exposed in the Vindhyan Basin and their implications in terms of basin evolution as well as global events.
\end{abstract}

Keywords: Vindhyan Basin; Geochemistry; Provenance and Tectonic Evolution; Chemostratigraphy; Paleoclimate

\section{Introduction}

The Archean-Proterozoic transition is marked by globally synchronous changes in tectono-thermal and climatic patterns. The tectono-thermal changes are broadly related to cooling of the mantle and extraction of the continental crust followed by stabilization of major cratons around 2.7-2.5 Ga (Condie and O'Neill, 2010). Cooling of the mantle is reflected by decrease in komatiite abundance and its $\mathrm{MgO}$ content, as well as decrease in $\mathrm{Ni} / \mathrm{Fe}$ ratio (Konhauser et al., 2017) and $\mathrm{Eu} / \mathrm{Eu}^{*}$ (Viehmann et al., 2015) in Banded Iron Formations. Peak in Re depletion age in mantle xenoliths around $2.7 \mathrm{Ga}$ suggest thickening of the continental lithosphere (Irvine et al., 2001; Carlson, 2005). In addition to this, increase in $\mathrm{Nb} / \mathrm{Th}$ and $\varepsilon_{\mathrm{Nd}(\mathrm{t})}$ in non-arc derived basalts are consistent with extraction of continental crust from the mantle. From a climatic aspect, a major oxygenation event, popularly known as the Great Oxidation Event (GOE) occurred during Paleoproterozoic around $\sim 2.3 \mathrm{Ga}$ (c.f., Holland, 2006) which substantially modified the biogeochemical cycles and is a crucial step towards development of a complex eukaryote dominated biosystem (Lyons et al., 2014). The Archean-Proterozoic transition also recorded development of widespread epicontinental seas with aerially extensive shelf sedimentation in the stable cratons (Eriksson, 1995). Globally, the Proterozoic sedimentation sites include the Kaapvaal Province, the Superior Province, the Pilbara Craton, the Baltic Shield, and the Indian Shield.

Starting from the Paleoproterozoic, the Indian Shield evidenced development of large-scale sedimentary basins, popularly known as Purana basins. Sedimentation in the Cuddapah Basin, which is the oldest among the Puranas, started around $1.9 \mathrm{Ga}$ ago (Anand, 2003; French and Heaman, 2010; Vadlamani et al., 2014) while the youngest Marwar Basin closed around $0.54 \mathrm{Ga}$ ago, the latter estimate being constrained by $\mathrm{U}-\mathrm{Pb}$ ages of detrital zircons (McKenzie et al., 2011). The opening and closure of the different Purana basins are considered to be related to the amalgamation and fragmentation of Proterozoic supercontinents Columbia and Rodinia (Basu and Bickford, 2015). The Vindhyan Basin, with an aerial extent of $178,000 \mathrm{Km}^{2}$ (Tandon et al., 1991), is the largest among the Purana basins of India (Chakraborty, 2006; Chakraborty et al., 2012). Globally, the Vindhyan Basin is the second largest Proterozoic sedimentary basin (Chakraborty, 2006; Chakraborty et al., 2012) comprising mostly

*Author for Correspondence: E-mail: ramananda@iisc.ac.in 
undeformed and unmetamorphosed sequences of siliciclastic and carbonate rocks. $\mathrm{Pb}-\mathrm{Pb}$ age dating of carbonates from the basal Kajrahat Formation suggests initiation of sedimentation in this basin $1729 \pm 110 \mathrm{Ma}$ ago (Sarangi et al., 2004) while $\mathrm{Pb}-\mathrm{Pb}$ ages of carbonates from Bhander Formation of the Upper Vindhyans suggest closure of the basin around 900 Ma ago (Gopalan et al., 2013). However, presence of Bitter Springs $\delta^{13} \mathrm{C}$ anomaly (George et al., 2018) and the $866 \pm 180 \mathrm{Ma} \mathrm{Pb}-\mathrm{Pb}$ age of the Balwan Limestone in the Rajasthan sector (Gopalanet al., 2013) suggest a younger Tonian closure age which is consistent with trace fossil studies (Chakrabarti, 1990). With an archive of approximately one billion years of sedimentation history starting from $\sim 1.8 \mathrm{Ga}$ ago, the Vindhyan Basin has the potential to record tectono-thermal and climatic changes during late Paleoproterozoic to early Neoproterozoic. The Vindhyan Basin has been studied thoroughly in terms of its geophysical, sedimentological, and palaeontological evolution (c.f., Adnan et al., 2015; Banerjee, 2000; Banerjee and Banerjee, 2010; Banerjee and Chopra, 1986; Banerjee and Jeevan Kumar, 2007; Banerjee et al., 2014; Bengtson et al., 2009; Bose et al., 2001, 2015; Chakraborty, 2004, 2011; Kumar, 2016; Mishra, 2011, 2015; Prasad and Asher, 2016; Prasad and Rao, 2006; Sarkar et al., 2004; Samanta et al., 2016; Seilacher, 1998; Sur et al., 2006; Verma and Shukla, 2015) while geochemical and isotopic studies have tried to address sediment provenance, tectonic evolution and sub-basin connectivity (c.f., Kumar et al., 2002; Ray et al., 2003; Chakrabarti et al., 2007; Shukla et al., 2019). This article reviews our current understanding of the origin and evolution of the Vindhyan Basin, primarily from a geochemical perspective, and its relation to Proterozoic events globally.

\section{Geology and Stratigraphy of the Vindhyan Basin}

The Vindhyan Basin (Fig. 1) is bound by the AravalliDelhi orogenic belt and the Great Boundary Fault to the west and the Central Indian Tectonic Zone to south covering a vast area from Chittorgarh in Rajasthan to Sasaram in Bihar (Verma, 1991; Kumar et al., 2001a). The northern part of the Vindhyan Basin is overlain by the Indo-Gangetic alluvium plain (Sengupta, 1996). The southern part of the Vindhyan Basin is overlain by the Deccan Traps (Krishnan, 1968). The Bundelkhand Granite Massif occurs at the central part of the basin and divides the basin into the Son Valley sub-basin in the east and the Chambal Valley subbasin in the Rajasthan sector (west). At the southeastern edge of the basin occurs a linear belt of metavolcanic and metasedimentary supracrustal sequence known as the Mahakoshal and Bijawar Group (Das et al., 1990). The sediments exposed to east of the Bundelkhand Massif are mostly undeformed and unmetamorphosed (Raza et al., 2002). In the Rajasthan sector, near the Great Boundary Fault, folded strata and vertically dipping beds are observed (Gilleaudeau et al., 2018). A generalised stratigraphy of the Vindhyan Supergroup in the Son, Chitrakut and Rajasthan sectors is shown in Fig. 2. Basement rocks of the Vindhyan Supergroup include the Bundelkhand Granite, the Paleoproterozoic Bijawar Group and Aravalli Supergroup (Kumar et al., 2002). In the western sector, Vindhyan sediments unconformably overly the Banded Gneissic Complex (BGC) (Raza et al., 2002). Sediments in the Vindhyan Basin are mostly dominated by sandstone, shale, limestone with intercalated tuff horizons. The Vindhyan Supergroup is subdivided into four Groups: Semri, Kaimur, Rewa, and Bhander (Krishnan, 1968). Semri Group is referred to as the Lower Vindhyan and Kaimur, Rewa, and Bhander groups as the Upper Vindhyan. The unconformity between the Lower and Upper Vindhyans has been characterized in several studies (e.g., Mandal et al., 2019).

Semri Group consists of repetitive sandstoneshale-carbonate sequences with the presence of volcaniclastic units. The depositional environment of the Semri Group is considered to be shallow water (Banerjee, 1974) to deeper water below storm wave base (Chakraborty et al., 1996b). The oldest carbonate unit in the eastern sector is Kajrahat Limestone which shows development of stromatolites (Kumar et al., 2002). In the upper part, Kajrahat Limestone also shows large fan-fabrics (Sharma and Kumar, 2012). This carbonate unit is considered to be deposited under subtidal to supratidal conditions (Banerjee, 1974). Presence of intraformational conglomerates suggest repetitive transgression and regression (Kumar et al., 2002). Gypsum layers are also reported from this unit which indicates an evaporative condition (Aktar, 1996). The Bhagwanpura Limestone in the Rajasthan sector is considered to be the stratigraphic equivalent of the Kajrahat Limestone of the Son Valley (Prasad, 1984; 


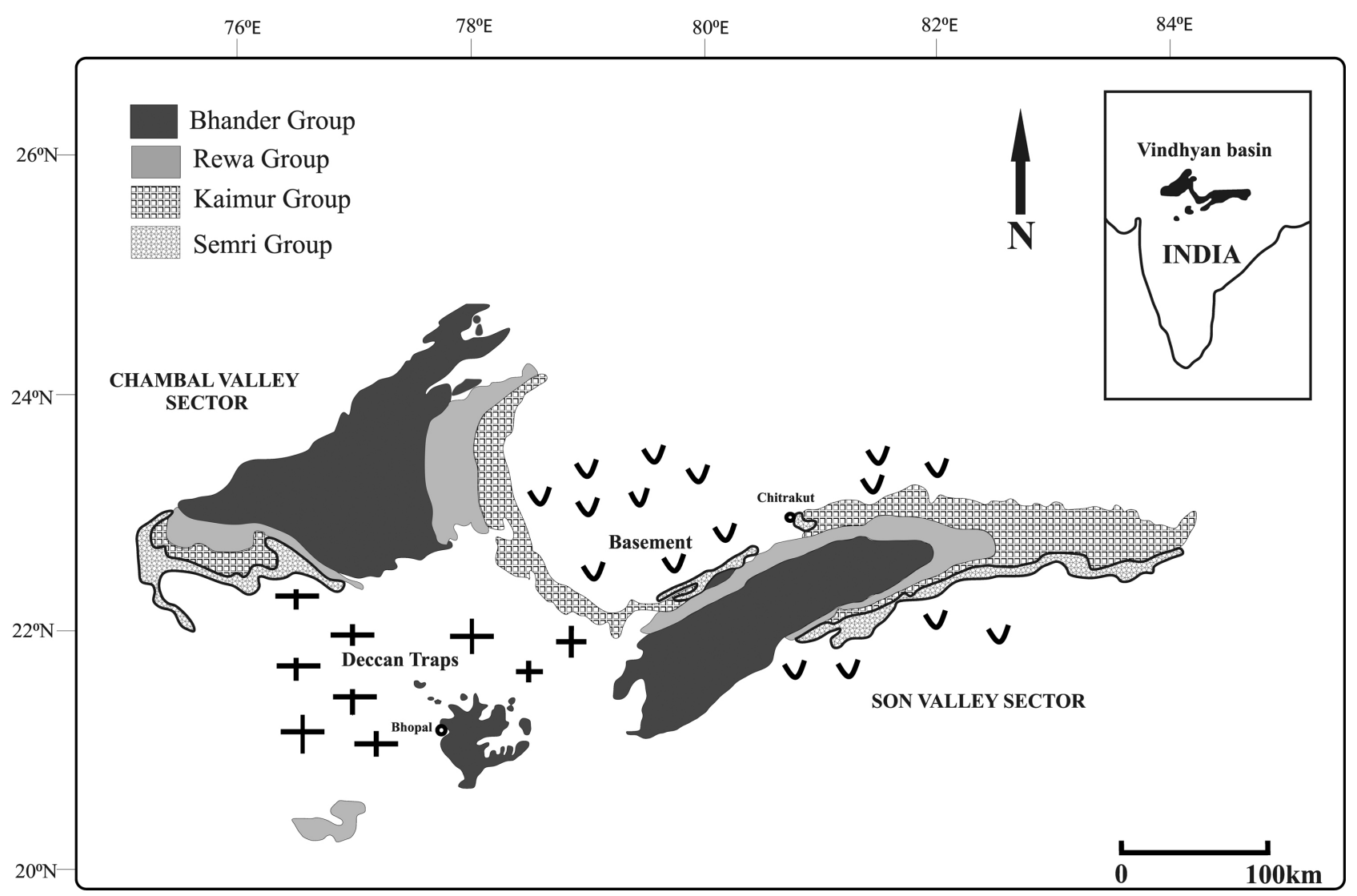

Fig. 1: A simplified geological map of the Vindhyan Basin, India (modified after Ray et al., 2003; Gilleadeau et al., 2018)

Banerjee and Chopra, 1986). However, this sequence is extensively dolomitic in nature with local occurrence of microbialites (Ray et al., 2003). The second and final phase of carbonate sedimentation in the Lower Vindhyan are represented by the Rohtas and Nimbahera Limestone horizons from the Son Valley and Rajasthan sector, respectively. In the Son valley, the Rohtas Limestone shows rhythmite-like intercalations between thin bedded limestone and shale. Poorly developed columnar stromatolites are also reported from the Rohtas Limestone (Kumar, 1977). This carbonate unit is deposited under subtidal to intertidal settings (Aktar, 1996). The Nimbahera Limestone from the Rajasthan sector is massive in nature and devoid of stromatolites and is considered to be deposited as a transgressional sequence (Prasad, 1981).

Presence of a thick silicified tuff unit, known as the Porcellanite Formation occurs in the Semri Group of Son Valley sector. Occurrence of this unit suggests active volcanism in the near vicinity of the basin during Lower Vindhyan sedimentation. Raza et al. (2002) reported presence of porcellanite beds with similar features as the Son Valley porcellanites within the Palri Shale of the Chambal Valley sector. Clays associated with the porcellanites (Mageswarii et al., 2019) and glauconites from the Lower Vindhyans (Mishra and Sen, 2017) also provide geochemical evidence of felsic volcanism.

Sedimentation in the Upper Vindhyan started after a prolonged depositional hiatus marked by the Dulchipur Conglomerate at the base of Kaimur Group (Kumar et al., 2002; Tripathi and Singh, 2015). Compared to the Lower Vindhyan, the Upper Vindhyan is mostly dominated by siliciclastic sequences with carbonate units occurring at the top. Presence of pyroclastic units in the Kaimur Group has been reported by Chakraborty et al. (1996a) and Sen and Mishra (2019). The clastic units of the Kaimur Group are deposited under fluvial to shallow marine conditions (Bhattacharya and Morad, 1993; Kumar et al., 2002). The next clastic sequence above Kaimur is the Rewa Group which is considered to be deposited under lagoonal conditions (Kumar et al., 2002). In the Upper 
Chambal Valley Sector

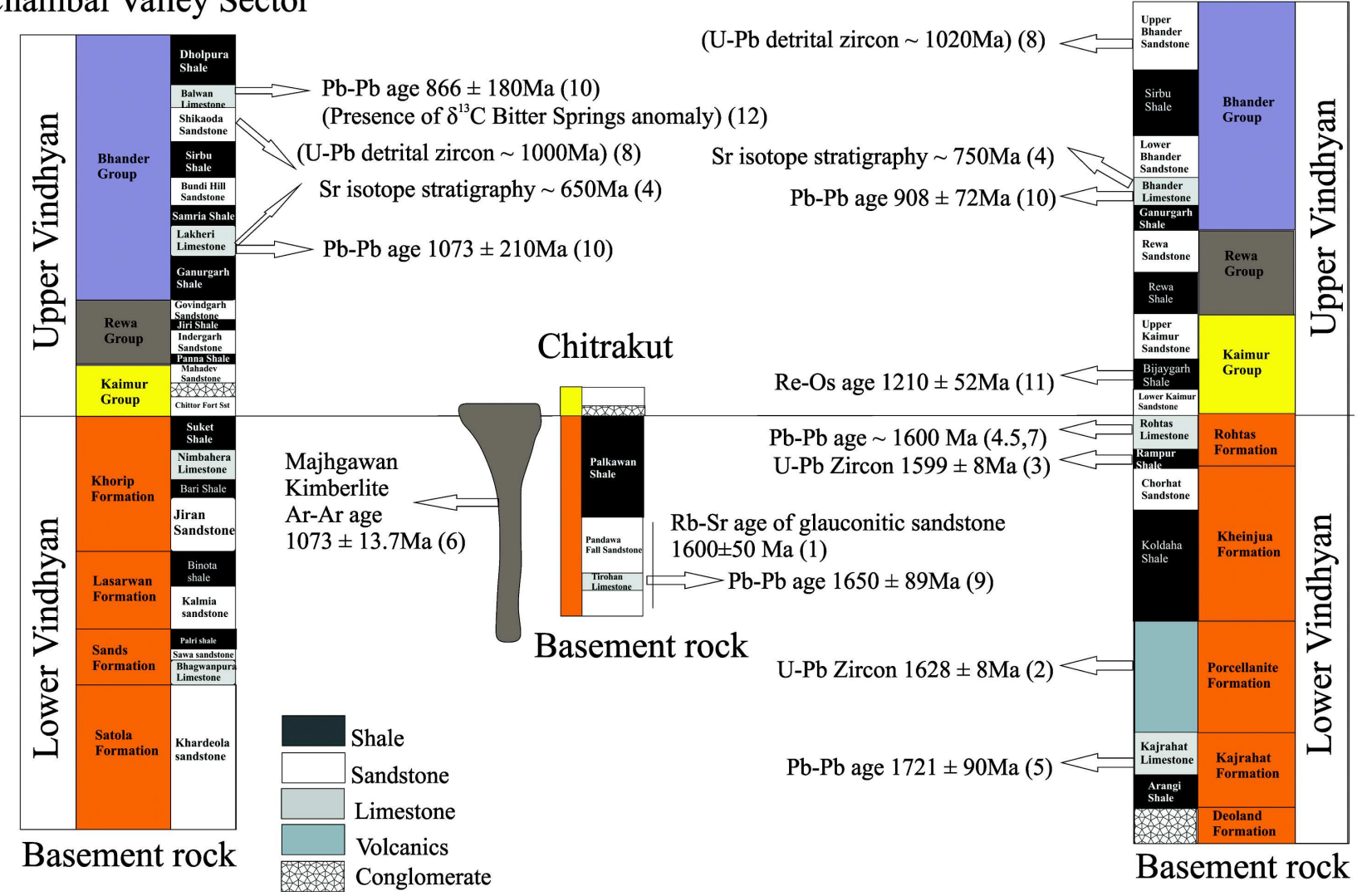

Fig. 2: A generalised stratigraphy of the Vindhyan Basin in the Son Valley, Chambal Valley, and Chitrakut sector (after Kumar et al., 2002; Ray et al., 2003; Gilleadeau et al., 2018) along with recent geochronological data. The geochronological data are taken from the following studies: 1. Kumar et al. (2001b), 2. Ray et al. (2002); 3. Rasmussen et al. (2002); 4. Ray et al. (2003); 5. Sarangi et al. (2004); 6. Gregory et al. (2006); 7. Chakrabarti et al. (2007); 8. Malone et al. (2008); 9. Bengtson et al. (2009); 10. Gopalan et al. (2013); 11. Tripathi and Singh (2015); 12. George et al. (2018)

Vindhyan, the Bhander Group carbonates overly the Ganurgarh Shale Formation. The carbonate units are referred as Nagod/Bhander Limestone in the central and eastern Vindhyan and as Lakheri Limestone in the Rajasthan sector. Presence of oolitic and intraclastic horizons with mega-ripples in the Son Valley sector suggest high energy conditions during deposition of these litho-units (Ray et al., 2003). Sedimentation in the central and eastern sector culminated with deposition of Upper Bhander Sandstone. Depositional environment for this unit is variably suggested to be near shore littoral (Kumar et al., 2002) to fluvial and deltaic (Soni et al., 1987). In the Rajasthan sector, sedimentation continued with the deposition of stromatolite bearing Balwan Limestone followed by the Dholpura Shale (Prasad et al., 1981; George et al., 2018).
Vindhyan Basin: A Billion-year Geologic Record

A significant shift in knowledge regarding Vindhyan geochronology has been documented in recent years. Earlier studies suggested that sedimentation in the Vindhyan Basin has been confined to Mesoproterozoic-Neoproterozoic (1400-600 Ma). Most of these ages are based on carbonaceous megafossils (Kumar and Srivastava, 1997; Rai et al., 1997, Kumar, 2001a), K-Ar (Vinogradov et al., 1964) and Fisson-Track technique (Srivastava et al., 1986). The reliability of these ages has been questioned as they have large errors (Ray et al., 2006). Rb-Sr isochron ages of $1140 \pm 24 \mathrm{Ma}, 1044 \pm 22 \mathrm{Ma}$ and $1067 \pm 31$ of a kimberlite and lamproite pipe intruding the Kaimur Group set the upper limit of Lower Vindhyan sedimentation (Crawford and Compston, 1969; Kumar et al., 1993). With technical advancements, measurements of the absolute 
radiometric ages have provided better constraints on the age of the Vindhyan Supergroup. Due to the absence of fossiliferous strata, the absolute age determination for Vindhyan Basin, similar to other Precambrian sedimentary systems, is constrained mostly by radiometric dating of intercalated volcanic tuffs, authigenic glauconites, and carbonate horizons.

A compilation of recent radiometric ages is given in Table 1 and Fig. 2. Rb-Sr age from Semri Group glauconites near Chitrakut area suggests onset of Lower Vindhyan sedimentation around 1600 Ma ago (Kumar et al., 2001b). This age is 200 Ma older than previously determined K-Ar age of glauconies from Semri Group by Vinogradov et al. (1964). A late Paleoproterozoic initiation age of the Vindhyan Basin is further supported by $\mathrm{U}-\mathrm{Pb}$ zircon dating of a rhyolitic tuff horizon from Deonar Formation, between Kajrahat and Rohtas Limestone, which yielded $1631 \pm 5$ Ma and 1631 \pm 1 Ma ages (Ray et al., 2002). Similar ages have been reported by Rasmussen et al. (2002) from $\mathrm{U}-\mathrm{Pb}$ zircon dating of tuff layers from Rampur Shale and Porcellanite Formation $(1602 \pm 10,1593 \pm 12$, $1628 \pm 8 \mathrm{Ma})$ and more recently, by Mishra et al. (2018), also by U-Pb dating of magmatic zircons from the Porcellanite Formation. In addition to this, $\mathrm{Pb}-\mathrm{Pb}$ isochron age of Kajrahat Limestone, which is the lowermost carbonate horizon in the Son Valley, is $1729 \pm 110$ and $1707 \pm 190$ Ma with a mean age of $1721 \pm 90 \mathrm{Ma}$ (Sarangi et al., 2004). Although the Pb$\mathrm{Pb}$ ages are associated with large errors, they suggest that the sedimentation in the Vindhyan Basin had started from the late Paleoproterozoic. A late Paleoproterozoic initiation is also consistent with a $1854 \pm 7 \mathrm{U}-\mathrm{Pb}$ age of underlying volcanic rocks in the Rajasthan sector (Deb et al., 2002). An unequivocal $\sim 1600$ Ma age of Rohtas Limestone has been reported by several authors $(1601 \pm 130,1599 \pm 48,1514 \pm 120$ Ma) (Ray et al., 2003; Sarangi et al., 2004, Chakrabarti et al., 2007). $\mathrm{Pb}-\mathrm{Pb}$ age dating of fossiliferous phosphorites near Chitrakut area suggest a similar depositional age for the Tirohann dolostone (Bengtson et al., 2009). These radiometric ages of the different lithologies from the Lower Vindhyan has set reasonable lower- and upper-time limits for the Semri Group sedimentation. However, diverse opinion exists regarding the depositional ages of the Upper Vindhyan sediments. Lower part of the Upper Vindhyan is dominated by clastic sequences and hence, limits the application for popularly used absolute age determination techniques. In addition to previously reported ages, Gregory et al. (2006) reported an ArAr age of $1073.5 \pm 13.7 \mathrm{Ma}$ from Majhgawan Kimberlite. This suggest that the Upper Vindhyan Bhander-Rewa Group is younger than $\sim 1075 \mathrm{Ma}$. A direct age of $1210 \pm 52 \mathrm{Ma}$ using Re-Os technique from the Bijaigarh Shale of the Kaimur Group suggests a long depositional hiatus as Kaimur Group is $\sim 400$ Ma younger than the underlying Semri Group (Tripathy and Singh, 2015). Based on Sr isotope stratigraphy, Kumar et al. (2002) and Ray et al. (2003) suggested that the Bhander Formation of the Upper Vindhyan is Neoproterozoic in age. Based on the least radiogenic ${ }^{87} \mathrm{Sr} /{ }^{86} \mathrm{Sr}$ value of 0.7065 , which is similar to the post-Sturtian ( $<750 \mathrm{Ma}$ ) sea water composition, Kumar et al. (2002) suggested that the Bhander Group carbonates are Neoproterozoic in age with depositional ages ranging from $\sim 700$ to $>540 \mathrm{Ma}$. Ray et al. (2003) provided a better constrained depositional age of 750-725 Ma for the Son Valley Bhander Limestone and a $\sim 650 \mathrm{Ma}$ depositional age for the Lakheri Limestone in Rajasthan. However, these ages were indirect estimations, based on Sr isotope evolution curve of marine carbonates (Shields and Veizer, 2002) and contrast with paleomagnetic evidence from Bhander and Rewa Group. Malone et al. (2008) that showed that the Bhander and Rewa palaeopoles bear resemblance with the 1073 Ma Majhgawan kimberlite palaeopoles suggesting an older, late Mesoproterozoic depositional age for the Upper Vindhyans. Detrital zircon geochronology from Upper Vindhyan sandstones also show absence of younger $(<1000 \mathrm{Ma}$ old) zircons (Malone et al., 2008; Turner et al., 2014), which support the paleomagnetic data of Malone et al. (2008). Direct age estimates of Upper Vindhyan sediments come from $\mathrm{Pb}-\mathrm{Pb}$ isochron ages of carbonates which show a depositional age of $908 \pm 72$ Ma for Son Valley Bhander Limestone and $1073 \pm 210$ Ma and $866 \pm 180$ Ma ages for Lakheri and Balwan Limestone units, respectively, in Rajasthan (Gopalan et al., 2013). These ages suggest that the Lakheri Limestone is stratigraphically older than Bhander Limestone while the younger age of the Balwan Limestone had placed its stratigraphic position higher than Bhander-Lakheri sequence (Gopalan et al., 2013). With younger $\mathrm{Pb}-\mathrm{Pb}$ isochron age estimates of Balwan Limestone and the presence of an overlying shale horizon (Prasad, 1984), the closure age of Upper Vindhyan sedimentation is expected to 
be even younger which contrasts with the paleomagnetic evidence. Additionally, George et al. (2018) reported presence of Bitter Springs $\delta^{13} \mathrm{C}$ anomaly from Balwan Limestone suggesting a younger 770-800 Ma closure age for Vindhyan Basin in the Rajasthan sector.

\section{Provenance and Tectonic Evolution of the Vindhyan Basin}

Sediment provenance studies can provide insights into the exhumation history of a terrain, tectonic evolution of a basin and reconstruction of continents (e.g., Millers and O'Nions, 1984; Basu et al., 1990). The techniques related for provenance analysis include sandstone petrography, heavy mineral analysis, major and trace elemental analysis, $\mathrm{Nd}$ isotope geochemistry, and $\mathrm{U}-\mathrm{Pb}$ zircon geochronology. However, geochemistry-based provenance studies of clastic sediments could be affected by post depositional alteration, recycling of sediments, limited information about the potential sources, similar signatures of different sources and variability within a single source (Nie et al., 2012). For the Vindhyan Basin, multiple approaches have been undertaken to understand the sediment provenance (Tandon et al., 1991; Raza et al., 2002; Gregory et al., 2006; Chakrabarti et al., 2007; Malone et al., 2008; Raza et al., 2010, 2012; Turner et al., 2014; Sen et al., 2014). Based on heavy mineral analysis, Tandon et al. (1991) suggested that the main source of Lower Vindhyan sediments is the Archean Bundelkhand Granite, which is the basement rock of the Vindhyan Basin. Sandstone petrography and heavy mineral analysis suggests that in addition to the Archean Bundelkhand Granite, the Proterozoic Mahakoshal Group could also act as a dominant sediment source for the Patherwa Formation in the basal part of the Semri Group in the Son Valley (Ahmad et al., 2009). Modal analysis and geochemistry of Upper Vindhyan Bhander sandstone suggests derivation from a recycled orogen source (Banerjee and Banerjee, 2010). Based on the petrographic characteristics, Sen et al. (2014) suggested a shift of provenance from Lower to Upper Kaimur Group of the Upper Vindhyans. It was suggested that the Lower Kaimur Group received sediments from the uplifted Bundelkhand craton while the Upper Kaimur Group received sediments from the Mahakoshal Group and the Chhotanagpur Gneissic Complex (CGC) of the Central Indian Tectonic Zone
(CITZ). This shift in provenance is related with tectonic activity of the CITZ around $1.1 \mathrm{Ga}$. Chakrabarti et al. (2007) provided an integrated approach using elemental and $\mathrm{Nd}$ isotope measurements from the Son Valley clastic sediments. Based on the difference in $\mathrm{Nd}$ isotopic composition between the basement Bundelkhand Granite and SonValley Vindhyan sediments, it was suggested that the Bundelkhand Granite is not the dominant source of sediments for the Vindhyans. In contrast, an extinct Andean-type arc is considered as a major source of sediments which is consistent with paleocurrent measurements (Chakrabarti et al., 2007). In the Rajasthan sector, geochemical evidence suggests that the Lower Vindhyans received sediments from granitoids and mafic enclaves of the Banded Gneissic Complex (BGC), which forms the basement (Raza et al., 2002; 2010). Geochemical evidence suggests that the upper Vindhyan clastic rocks from the Rajasthan sector received sediments mostly from stable cratonic sources with the Kaimur Group of rocks being derived from a TTG-like source. Immobile trace element mixing models suggests components of unidentified gneiss, TTG, mafic enclaves, and Berach Granite of the BGC in Kaimur Group sediments while Rewa and Bhander group sediments show compositions suggesting variable mixing between sources comprising gneiss, mafic enclaves and the Berach Granite (Raza et al., 2012). Mixing models coupled with paleocurrent measurements suggest that the Bundelkhand Granite Gneiss Complex (BGCC) and the Chotanagpur Granite Gneiss Complex (CGGC) were the dominant sources for Rewa and Bhander Groups in the Rajasthan sector (Raza et al., 2012). Based on the $\mathrm{Nd}$ isotopic composition of Rajasthan Vindhyan sediments, Shukla et al. (2019) suggested that in the Rajasthan sector, the lower Vindhyan received sediments from BGC and a younger magmatic arc, while in the Upper Vindhyan the provenance has been shifted to pre-1.7 Ga rocks of the Aravalli and Delhi supergroups.

Malone et al. (2008) and Turner et al. (2014) provided additional insights on the provenance and closure age of the Vindhyan Basin from $\mathrm{U}-\mathrm{Pb}$ ages of detrital zircons. Detrital zircon geochronology from the Upper Bhander Sandstone of Rajasthan shows that the most prominent peak is at $1.6 \mathrm{Ga}$, which is interpreted as inputs from the Lower Vindhyan Deonar Porcellanite the $1.85 \mathrm{Ga}$ and $1.8 \mathrm{Ga}$ peaks 
correlated with the Hindoli Group and Banded Gneissic Complex, respectively, 1.4-1.1 Ga peaks suggesting derivation from the Delhi Fold Belt, and the younger $1.02 \mathrm{Ga}$ peak corresponds to $1.0 \mathrm{Ga}$ old regional volcanism (Malone et al., 2008). As noted in the previous section, composite of detrital zircon U$\mathrm{Pb}$ ages show absence of $<1000 \mathrm{Ma}$ old zircons in the sediment population, which is interpreted as closure of the basin around 1.0 Ga (Malone et al., 2008; McKenzie et al., 2011; Turner et al., 2014). This observation is particularly significant as sedimentary basins on the Bastar Craton also show similar closure ages (Basu et al., 2008; Mukherjee et al., 2012). It has been suggested that the collision between the Eastern Ghats Mobile Belt (EGMB) and Antarctica around $1.0 \mathrm{Ga}$, due to the formation of the Rodinia supercontinent, might have led to the closure of these sedimentary basins (Turner et al., 2014). The above arguments are, however, not consistent with the younger $\mathrm{Pb}-\mathrm{Pb}$ ages (Goapalan et al., 2013) and presence of Neoproterozoic $\delta^{13} \mathrm{C}$ bitter spring anomaly in the Balwan Limestone as well as presence of a shale horizon above it in the Rajasthan sector, which suggests that sedimentation continued even after 1.0 Ga (George et al., 2018).

Differences in opinion exist regarding the tectonic evolution of the Vindhyan Basin (Raza and Cassyap, 1996; Bose et al., 2001; Chakraborty 2006; Chakrabarti et al., 2007; Raza et al., 2012; Basu and Bickford 2015; Bickford et al., 2017). Traditionally the Vindhyan Basin as well as the other Purana basins are considered as intracratonic sedimentary basins (Holland, 1906) and are broadly considered to have developed in a continental rift setting (Chaudhuri et al., 2002). Based on limited deformation and metamorphism of Vindhyan sediments along with geophysical evidence showing rifting across faults, Bose et al. (2001) suggested an intracratonic rift origin for the Vindhyan Basin with tectonism-driven sedimentation cycles. Based on a sequence stratigraphy study, it was suggested that all the major flooding events in this basin correlated with volcanic activity and hence, were related to tectonic subsidence of the basin (Bose et al., 2001). In contrast, it has been suggested that the early Vindhyan sedimentation took place in a foreland basin setting (Acharya et al., 2003; Chakrabarti et al., 2007; Raza et al., 2009). This suggestion is based on the geochemical and $\mathrm{Nd}$ isotope signatures of the porcellanites from the Semri
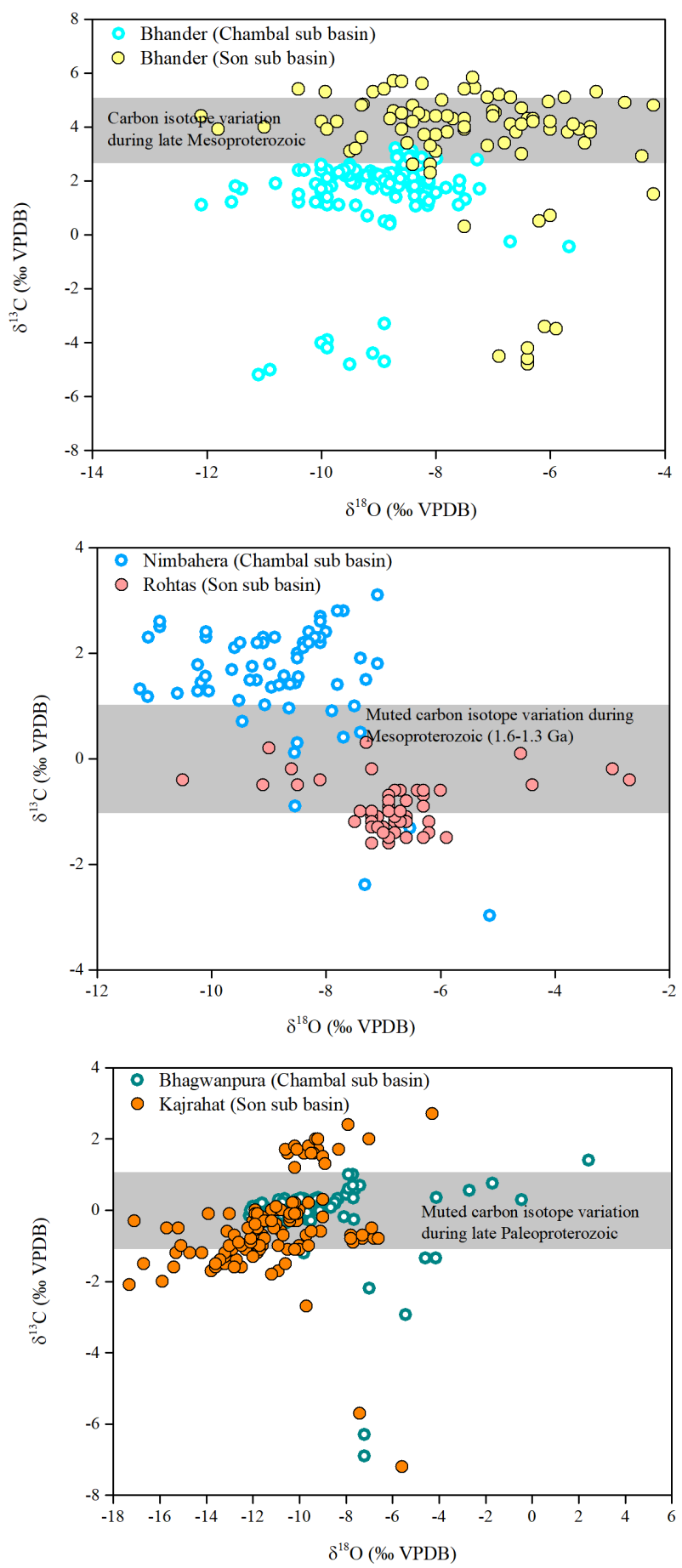

Fig. 3: A literature compilation of the $\delta^{13} \mathrm{C}$ and $\delta^{18} \mathrm{O}$ composition of carbonates from different stratigraphic units from the Vindhyan basin, India (data compilation from Kumar et al. (2002); Ray et al. (2003); Gilleadeau et al. (2018). The grey bar is showing 'muted' $\boldsymbol{\delta}^{13} \mathbf{C}$ variation during Paleo-Mesoprotero-zoic (Kah et al., 1999, 2012; Frank et al., 2003)

Group. Geochemical and $\mathrm{Nd}$ isotope signatures of Deonar Porcellanites suggest derivation from an 
Andean-type arc located to the south of the basin. This tectonic model suggests that theVindhyan Basin developed as a foreland basin as a result of collision between Bundelkhand Craton in the North and Bhandara/Bastar Craton in the south (Chakrabarti et al., 2007).

By re-interpreting existing geophysical data along with new geochemical data from basal volcanic units from both the Rajasthan and the Son sector, Raza et al. (2009) further supported the foreland model of Chakrabarti et al. (2007). The position of Vindhyan Basin between two Proterozoic mobile belts (i.e., the Aravalli Delhi Fold Belt and the Central Indian Tectonic Zone) is suggestive of formation of the basin in relation to an active tectonic setting (Raza and Casshyap, 1996). Geochemical evidence from basal volcanics further suggests that the Khairmalia volcanic unit in the Rajasthan and Jungel volcanics in the Son sector have a continental flood basalt and ocean island basalt origin (Raza et al., 2009). Presence of rift related volcanism suggests an extensional tectonic regime during the initiation of Vindhyan Basin. Following the initiation phase, Vindhyan Basin had evolved to a peripheral foreland basin during its course of evolution (Raza and Casshyap, 1996). Based on several lines of geophysical, structural, sedimentological and geochemical evidences, these authors suggested that the Proterozoic Vindhyan Basin originated as a rift which evolved into a foreland basin having similar geological features of Himalayan Foreland Basin (HFB). Recently, based on the $\mathrm{Nd}$ isotopic composition of the Rajasthan Vindhyan sediments, Shukla et al. (2019) suggested that Lower Vindhyan received sediments from a younger magmatic arc. Presence of a younger magmatic arc in the near vicinity of Vindhyan Basin at the time of deposition, as well as presence of the Great Boundary Fault at the western margin suggest a foreland depositional setting for the Vindhyan Basin. A foreland basin model for the Rajasthan sector have also been established by seismic reflection images, gravity and magnetotelluric data (Mandal et al., 2018).

Bickford et al. (2017) however suggested that occurrence of the felsic volcanic events can also be explained without invoking the foreland basin concept. It was also suggested that flat-lying Vindhyan sedimentary units cannot be explained by foreland model. Based on the Hf isotope composition of zircons from $1642 \pm 7$ Ma rhyolitic flow within the Porcellanite Formation in the Lower Vindhyan, Bickford et al. (2017) suggested derivation from an old felsic crust due to the far-field effect of $1.65 \mathrm{Ga}$ collisional events due to the amalgamation of the Columbia supercontinent. Based on geochemical characteristics of the $\sim 1.6$ Ga Deonar Pyroclastics of the Porcellanite Formation, Mishra et al. (2017b) further suggested formation due to mixing between mantle-derived rocks and average continental crust possibly under a continental rift environment. A similar conclusion has also been reached from the Chopan unit of the Porcellanite Formation (Mishra et al., 2017a).

\section{Chemostratigraphic Studies of the Vindhyan Basin: Implications for Correlations of The Sub- Basins and Mid-Proterozoic Climate Reconstruction}

\section{Correlation Between the Son Valley and Chambal Valley Sub-basins}

The Bundelkhand Granite Complex divides the Vindhyan Basin into two sub-basins, the Son Valley sub-basin to the east and the Chambal Valley subbasin to the west. Correlation of the lithological units in these two sub-basins is often difficult because of the extensive spatial distribution of the basin. Subbasinal correlation has been attempted based on lithological similarities and the relative stratigraphic position of these sedimentary units (Prasad, 1984; Sastry and Moitra, 1984; Soni et al., 1987). Chemostratigraphic correlation of the limestone units from the two sub-basins, using $\mathrm{C}$ and $\mathrm{Sr}$ isotope systems, has also been attempted for sub-basinal correlation (Kumar et al., 2002; Gilleaudeau et al., 2018). This approach is based on the assumption that conservative elements like $\mathrm{Sr}$, which have a much longer residence time compared to ocean mixing timescales, show similar isotopic compositions in all parts of the global ocean at any instant of time. Hence, carbonates precipitating from seawater are expected to show comparable isotopic signatures if they are stratigraphically equivalent. Although, this technique has been widely used in Phanerozoic stratigraphy, for ancient carbonates, this approach is particularly challenging as carbonates are prone to diagenetic alterations which affects the chemistry of some of these conservative elements. In general, $\delta^{18} \mathrm{O}$ and ${ }^{87} \mathrm{Sr} /$ ${ }^{86} \mathrm{Sr}$ values are more susceptible to diagenetic 
Chambal Valley

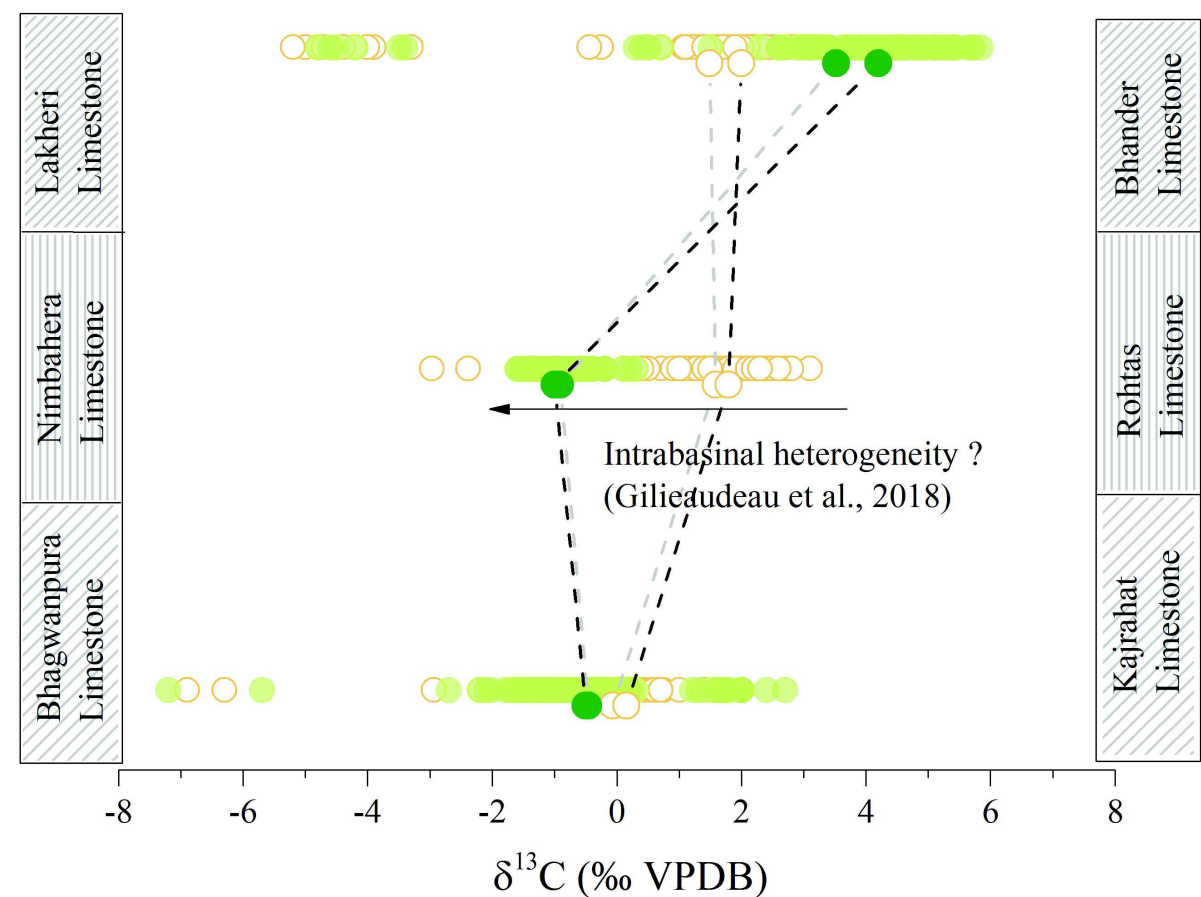

Son valley

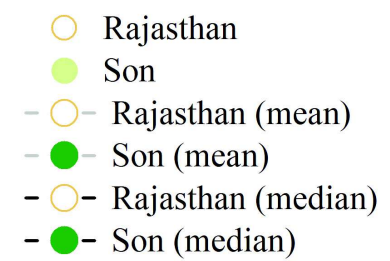

Fig. 4: $\delta^{13} \mathrm{C}$ variation between the carbonate units from Son and Chambal sub-basin record a large range (Kumar et al., 2002; Ray et al., 2003; Gilleadeau et al., 2018). Mean and Median values show Lower and Upper Vindhyan carbonates have different $\delta^{13} \mathrm{C}$ composition. This variation can also be explained as intrabasinal heterogeneity

alterations by meteoric water compared to $\delta^{13} \mathrm{C} . \mathrm{Mn} /$ $\mathrm{Sr}, \mathrm{Rb} / \mathrm{Sr}, \delta^{18} \mathrm{O}$ composition of Vindhyan carbonates were evaluated for possible diagenetic alterations and only samples which have preserved their primary isotopic signatures were considered (Kumar et al., 2002; Ray et al., 2003; Gilleadeau et al., 2018). Ray et al. (2003) presented a theoretical approach considering close system water-rock alteration and its effect on $\mathrm{C}, \mathrm{O}$, and $\mathrm{Sr}$ isotope system.

The ${ }^{13} \mathrm{C}$ composition of Bhagwanpura Limestone from the Chambal Valley sub-basin is different from the so-called stratigraphically equivalent Kajrahat Limestone of the Son Valley sub-basin. Extensive dolomitized nature of Bhagwanpura Formation limits the application of $\mathrm{Sr}$ isotope chemostratigraphy. The younger carbonate horizons from the Lower Vindhyan Semri Group are the Rohtas Formation in the Son Valley and Nimbahera Formation in the Rajasthan sector. Both carbonate horizons record different $\delta^{13} \mathrm{C}$ compositions: Rohtas $\delta^{13} \mathrm{C}$ ranging from -1.1 to $-1.5 \%$ ond Nimbahera from 2.3-3.1\%o. (Kumar et al., 2002; Ray et al., 2003). In the Upper Vindhyans, carbonates from Bhander Formation in the Son Valley and Lakheri Formation in the Rajasthan sector show different ${ }^{87} \mathrm{Sr} /{ }^{86} \mathrm{Sr}$ compositions. Based on the $\mathrm{Sr}$ isotope compositions, Ray et al. (2003) suggested that Lakheri Limestone is relatively younger. Both Ray et al. (2003) and Kumar et al. (2002) reported variable $\delta^{13} \mathrm{C}$ composition of Upper Vindhyans carbonates. In general, Bhander Formation carbonates in the Son Valley sub-basin show $\delta^{13} \mathrm{C}$ ranging from 2.7 to $5.1 \%$ o (Kumar et al., 2002; Ray et al., 2003; Gilleadeau et al., 2018). Ray et al. (2002) reported significantly depleted $\delta^{13} \mathrm{C}$ composition ( -3.5 to $-4.8 \%$ o) from Ramnoi section of the Bhander Group in the Son Valley sub-basin while Lakheri Formation carbonates show $\delta^{13} \mathrm{C}$ of $1.5 \pm 1 \%$ o (Ray et al., 2003; Gilleadeau et al., 2018). Kumar et al. (2002) reported strongly depleted $\delta^{13} \mathrm{C}$ values from the Lakheri Formation ranging from -3.3 to $-5.2 \%$ o. Kumar et al. (2002) suggested that these carbonates strongly resemble cap carbonates overlying the Neoproterozoic glacial deposits. Also, presence of a tilloid horizon underlying Lakheri Limestone might strengthen this claim. 


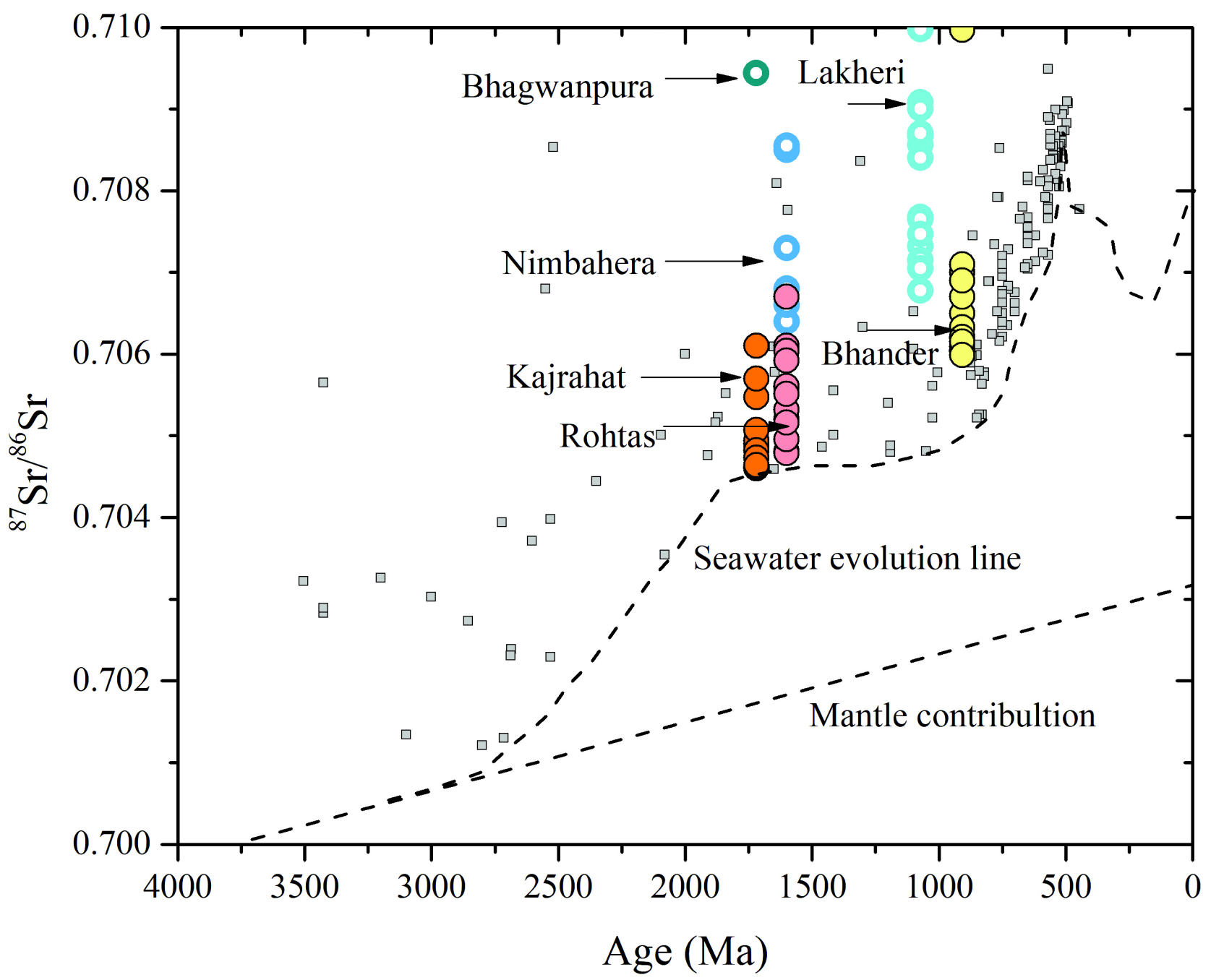

Fig. 5: A compilation of ${ }^{87} \mathrm{Sr} /{ }^{86} \mathrm{Sr}$ composition of the Vindhyan carbonates (Kumar et al., 2002; Ray et al., 2003). Seawater Sr isotope evolution line has been reconstructed using the lowest ${ }^{87} \mathrm{Sr} /{ }^{86} \mathrm{Sr}$ composition of marine carbonates at any instant of time (filled square) (Sheilds and Veizer, 2002). ${ }^{87} \mathrm{Sr} /{ }^{86} \mathrm{Sr}$ composition of the Vindhyan carbonates are plotted against their absolute radiometric ages (Ray et al., 2003; Sarangi et al., 2004; Chakrabarti et al., 2007; Gopalan et al., 2013). Chambal Valley carbonates show higher ${ }^{87} \mathrm{Sr} /{ }^{86} \mathrm{Sr}$ composition compared to Son Valley carbonates, possibly due to diagenetic alterations

However, strongly negative $\delta^{13} \mathrm{C}$ from both Ramnoi section of the Son Valley sub-basin and few samples from Rajasthan sector reported by Kumar et al. (2002) requires further investigation. Based on $\mathrm{C}$ and $\mathrm{Sr}$ isotope composition of carbonates from both subbasins, Kumar et al. (2002) and Ray et al. (2003) suggested that these supposedly equivalent formations are not exclusively coeval (Figs. 3, 4, 5). However, chemostratigraphic application during the PaleoMesoproterozoic is particularly difficult due to the absence of any significant excursion in $\delta^{13} \mathrm{C}$ values (Kah, 1999, 2012; Frank et al., 2003). Additionally, difference in $\delta^{13} \mathrm{C}$ composition does not necessarily mean that the sub-basins were not coeval as substantial difference in $\delta^{13} \mathrm{C}$ can also be observed because of intrabasinal heterogeneity (Gilleadeau et al., 2018). This has been observed in the case of Phanerozoic as well as Proterozoic sedimentary basins (Holmden et al., 1998; Gilleaudeau and Kah, 2015). In the Mesoproterozoic, $\delta^{13} \mathrm{C}$ gradient can result due to difference in organic carbon mineralization pathways under low oxygen availability (Gilleaudeau and Kah, 2013, 2015). Gilleadeau et al. (2018) suggested that progressively lighter values from Rajasthan to Son Valley sub-basin during the Lower Vindhyan can be interpreted as intrabasinal heterogeneity in $\delta^{13} \mathrm{C}$ 
composition. Depleted $\delta^{13} \mathrm{C}$ in Rohtas Limestone is consistent with restricted environment in the Son subbasin, compared to Rajasthan sector. Paleocurrent analysis also supports open ocean connection in the west. As a result, the carbonate horizons in Lower Vindhyan, having different $\delta^{13} \mathrm{C}$ compositions could be stratigraphic equivalents. However, in the Upper Vindhyan, $\delta^{13} \mathrm{C}$ composition between two carbonate horizons is up to $5 \%$, compared to Lower Vindhyan ( 2 to $4 \%$ ). This difference in $\delta^{13} \mathrm{C}$ composition is higher than any Mesoproterozoic sedimentary basin studied. In addition, excluding strongly negative $\delta^{13} \mathrm{C}$ of glacial origin from the dataset of Kumar et al. (2002), the compositions of the carbonates from the Upper Vindhyan Rajasthan sector is consistent with late Mesoproterozoic age where as Bhander Group carbonates in the Son sub-basin record strongly positive $\delta^{13} \mathrm{C}$ ranging from +4 to $+6 \%$ which is common in Neoproterozoic rocks (Gilleadeau et al., 2018). Based on this observations Gilleadeau et al. (2018) suggested that carbonate horizons in the Upper Vindhyan are not stratigraphic equivalents.

\section{Mid-Proterozoic Climate Reconstruction}

Several independent lines of geological and geochemical evidences suggest that the oxygenation of the Earth's atmosphere occurred in two broad steps (Farquhar, 2000; Holland, 2006; Lyons et al., 2014). The first rise of atmospheric oxygen took place around 2.45-2.2 Ga ago, which is known as the Great Oxidation Event (GOE) and the second rise occurred around late Neoproterozoic (800-542Ma) (Farquhar, 2000; Lyons et al., 2014). Compared to the dramatic changes in Paleoproterozoic and Neoproterozoic, the Mesoproterozoic (1.6-1.0 Ga) has long been recognized to be a period of biogeochemical stasis (Kah et al., 2004). The time period extending from 1.8-0.8 Ga is also notable for the environmental, evolutionary and tectonic stability and famously known as the 'Earth's middle age' or 'The boring billion' (Holland, 2006; Lyons et al., 2014). The redox evolution of the ocean-atmosphere system during the boring billion is still not fully understood but is important in order to understand the radiation of complex life on Earth. The Vindhyan Basin with a prolonged sedimentation history is an excellent archive for understanding the ocean-atmosphere evolution during the mid-Proterozoic. Sarkar et al. (2010) reported $\delta^{34} \mathrm{~S}$ composition of sedimentary pyrites from the Vindhyan Basin as well as from the other Purana basins (e.g. Cuddapah and Chhattisgarh). These sedimentary pyrites show highly positive $\delta^{34} \mathrm{~S}$ composition of $>25 \%$ as compared to extremely negative phanerozoic $\delta^{34} \mathrm{~S}$ values (Canfield and Raiswell, 1999; Strauss, 1999) suggesting an euxinic ocean with low concentration of marine sulphates (Sarkar et al., 2004). Based on TOC composition and Mo concentration of Vindhyan shales from different stratigraphic units, Singh et al. (2018) suggested that during the initial stage the Vindhyan sedimentation, the water-mass was stratified and euxinic in nature. However, this euxinic condition did not prevail during the entire course of evolution of the basin. During the Upper Vindhyan sedimentation, the Vindhyan watermass was nearly oxic in nature.

\section{Summary}

The Vindhyan Basin is the largest among the Purana basins of India. Extensive sedimentary units comprising mostly undeformed and unmetamorphosed sediments makes the Vindhyan Basin an excellent record of Proterozoic geologic events. Radiometric ages from Vindhyan Basin suggests a late Paleoproterozoic initiation age. In the Son Valley sector, the sedimentation is considered to have ceased around $\sim 1000 \mathrm{Ma}$ ago. However, very recent radiometric and isotopic studies suggest that in the Rajasthan sector sedimentation continued up to early Neoproterozoic. Two contrasting tectonic evolutionary histories have been suggested for the Vindhyan Basin: geochemical and isotopic studies suggest a foreland basin depositional model which contrasts with the traditional intracratonic model. The extent of correlation of the lithounits between the two Vindhyan sub-basins remains an open question. Variation in $\mathrm{C}$ isotopic composition of carbonate units have been traditionally interpreted as a lack of correlation between the two sub-basins. However, this variation can also be due to intrabasinal $\mathrm{C}$ isotopic heterogeneity. Difference in opinion exists regarding the redox structure of mid-Proterozoic oceans. $\delta^{34} \mathrm{~S}$ studies suggest Vindhyan water-mass was mostly euxinic in nature. However, the euxinic condition was not persistent during all stages of basin evolution. 


\section{References}

Acharya S K (2003) A plate tectonic model for Proterozoic crustal evolution of Central Indian tectonic Zone Gondwana Geol Mag 7 9-31

Adnan A, Shukla U K, Verma A and Shukta T (2015) Lithofacies of transgressive-regressive sequence on a carbonate ram in Vindhyan basin (Proterozoic): a case of tidal-flat origin from central India Arab J Geosci 8 6985-7001

Aktar K (1996) Facies, sedimentation processes and environments in the Proterozoic Vindhyan Basin, India In: Bhattacharya, A. (Ed.), Recent Advances in Vindhyan Geology Geological Society of India Memoir 36 127-136

Ahmad A, Rao L, Majid A and Kaur H (2009) Depositional Environment, Provenance and Diagenesis of Patherwa Formation Sandstone (Semri Group), Son Valley, Uttar Pradesh Proceedings of Indian National Science Academy 75 79-88

Anand M (2003) Early Proterozoic Melt Generation Processes beneath the Intra-cratonicCuddapah Basin, Southern India Journal of Petrology 44 2139-2171 https://doi.org/10.1093/ petrology/egg073

Basu A and Bickford M E (2015) An Alternate Perspective on the Opening and Closing of the Intracratonic Purana Basins in Peninsular India Journal of Geological Society of India $\mathbf{8 5}$ $5-25$

Banerjee A and Banerjee D M (2010) Modal analysis and geochemistry of two sandstones of the Bhander Group (Late Neoproterozoic) in parts of the Central Indian Vindhyan basin and their bearing on the provenance and tectonics Journal of Earth System Science 119 825-839

Banerjee D M and Chopra J (1986) Morphometric analysis of Proterozoic stromatolites from India - preliminary report on testing of a new technique Precambrian Research 33 $265-282$

Banerjee I (1974) Barrier coastline sedimentation model and the Vindhyan example. In: De, A. (Ed.), contributions to the Earth and Planetary Sciences (Golden Jubilee volume) Geol Min Met Soc India 46 101-127

Banerjee S (2014) Palaeoenvironmental and biostratigraphic implications of microbial mat-related structures: Examples from the modern Gulf of Cambay and the Precambrian Vindhyan Basin, India Journal of Palaeogeography 3 127144

Banerjee S (2000) Climatic Versus Tectonic Control on Storm Cyclicity in Mesoproterozoic Koldaha Shale, Vindhyan Supergroup, Central India Gondwana Research 3 521528
Banerjee S and Jeevankumar S (2007) Facies and depositional sequence of the Mesoproterozoic Rohtas Limestone: Eastern Son valley, Vindhyan basin Journal of Asian Earth Sciences 30 82-92

Basu A, Patranabis-Deb S, Schieber J and Dhang P C (2008) Stratigraphic position of the $\sim 1000 \mathrm{Ma}$ Sukhda Tuff (Chhattisgarh Supergroup, India) and the 500Ma question Precambrian Research 167 383-388

Basu A R, Sharma M and DeCelles P G (1990)Nd, Sr-isotopic provenance and trace element geochemistry of Amazonian foreland basin fluvial sands, Bolivia and Peru: implications for ensialic Andean orogeny Earth and Planetary Science Letters 100 1-17

Bengtson S, Belivanova V, Rasmussen B and Whitehouse M (2009) The controversial "Cambrian" fossils of the Vindhyan are real but more than a billion years older Proceedings of the National Academy of Sciences 1067729 7734

Bhattacharya A and Morad S (1993) Proterozoic braided ephemeral fluvial deposits: an example from the Dhandraul Sandstone Formation of the Kaimur Group, Son valley, India Sedimentary Geology 84 101-114

Bickford M E, Mishra M, Mueller P A, Kamenov G D, Schieber $\mathrm{J}$ and Basu A (2017) U-Pb Age and Hf Isotopic Compositions of Magmatic Zircons from a Rhyolite Flow in the Porcellanite Formation in the Vindhyan Supergroup, Son Valley (India): Implications for Its Tectonic Significance The Journal of Geology 125 367-379

Bose P K, Sarkar S, Chakrabarty S and Banerjee S (2001) Overview of the meso- to neoproterozoic evolution of the Vindhyan basin, central India Sedimentary Geology 141-142 395419

Bose P K, Sarkar S, Das N G, Banerjee S, Mandal A and Chakraborty N (2015) In Mazumder R and Eriksson P G (Ed.), Precambrian Basins of India: Stratigraphic and Tectonic Context Geological Society, London, Memoirs 43 85-102

Canfield DE (1999)The evolution of the sulfur cycle. American Journal of Science 299 697-723

Carlson R W (2005) Physical, chemical, and chronological characteristics of continental mantle Reviews of Geophysics $43 \mathrm{https} / / /$ doi.org/10.1029/2004RG000156

Chakrabarti A (1990) Traces and dubiotraces: examples from the so-called Late Proterozoic siliciclastic rocks of the VindhyanSupergroup around Maihar, India Precambrian Res 47 141-153

Chakrabarti R, BasuA andChakrabarti A (2007) Trace element and $\mathrm{Nd}$-isotopic evidence for sediment sources in the mid- 
Proterozoic Vindhyan Basin, central India Precambrian Research 159 260-274

Chakraborty C (2006) Proterozoic intracontinental basin: The Vindhyan example Journal of Earth System Science 115322

Chakraborty P P, Sarkar S and Patranabis-Deb S(2012) Tectonics and Sedimentation of Proterozoic Basins of Peninsular India Proceedings of the Indian National Science Academy 78 393-400

Chakraborty P P (2011) Slides, soft-sediment deformations, and mass flows from Proterozoic Lakheri Limestone Formation, Vindhyan Supergroup, central India, and their implications towards basin tectonics Facies 57 331-349

Chakraborty P P (2004) Facies architecture and sequence development in a Neoproterozoic carbonate ramp: Lakheri Limestone Member, Vindhyan Supergroup, Central India Precambrian Research 132 29-53

Chakraborty P P, Banerjee S, Das N G, SarkarS and Bose P K (1996a) Volcaniclastics and their sedimentological bearing in Proterozoic Kaimur and Rewa groups in Central India. In Bhattacharya, A. (Ed.), Recent Advances in Vindhyan Geology, Mem Geol Soc India 36 59-75

Chakraborty T, Sarkar S, Chaudhuri A K and Das Gupta S (1996b) Depositional environment of Vindhyan and other Purana basins: A reappraisal in the light of recent findings. In: Bhattacharya A, (Ed.), Recent advances in Vindhyan Geology, Mem Geol Soc India 26 101-126

Chaudhuri A K, SahaD, Deb G K, Patranabis-Deb S, Mukherjee M K and Ghosh G (2002) The Purana Basins of Southern Cratonic Province of India - A Case for Mesoproterozoic Fossil Rifts Gondwana Research 5 23-33

Condie K C and O’Neill C (2010) The Archean-Proterozoic boundary: 500 my of tectonic transition in Earth history American Journal of Science 310 775-790

Das L K, Mishra D C, Ghosh D and Banerjee B (1990) Geomorpho-tectonics of the basement in a part of upper Son Valley of the Vindhyan Basin J Geol Soc India 35 445458

Deb M, Thorpe R and Krstic D (2002) Hindoli Group of Rocks in the Eastern Fringe of the Aravalli-Delhi Orogenic BeltArchean Secondary Greenstone Belt or Proterozoic Supracrustals Gondwana Research 5 879-883

Eriksson K A (1995) Crustal growth, surface processes, and atmospheric evolution on the early Earth Geological Society, London, Special Publications 95 11-25

Farquhar J (2000) Atmospheric Influence of Earth's Earliest Sulfur Cycle Science $\mathbf{2 8 9}$ 756-758
Frank T D, Kah L C and Lyons T W (2003) Changes in organic matter production and accumulation as a mechanism for isotopic evolution in the Mesoproterozoic ocean Geological Magazine $140397-420$

French J E and Heaman L M (2010) Precise U-Pb dating of Paleoproterozoic mafic dyke swarms of the Dharwar craton, India: Implications for the existence of the Neoarchean supercraton Sclavia Precambrian Research 183 416-441

George B G, Ray J S, Shukla A D, Chatterjee A, Awasthi N and Laskar A H (2018) Stratigraphy and geochemistry of the Balwan Limestone, Vindhyan Supergroup, India: Evidence for the Bitter Springs $\delta^{13} \mathrm{C}$ anomaly Precambrian Research 313 18-30

Gilleaudeau G J and Kah L C (2015) Heterogeneous redox conditions and a shallow chemocline in the Mesoproterozoic ocean: Evidence from carbon-sulfuriron relationships Precambrian Research 257 94-108

Gilleaudeau G J and Kah L C (2013) Carbon isotope records in a Mesoproterozoic epicratonic sea: Carbon cycling in a lowoxygen world Precambrian Research 228 85-101

Gilleaudeau G J, Sahoo S K, Kah L C, Henderson M A and Kaufman A J (2018) Proterozoic carbonates of the Vindhyan Basin, India: Chemostratigraphy and diagenesis Gondwana Research 57 10-25

Gopalan K, Kumar A, Kumar S and Vijayagopal B (2013) Depositional history of the Upper Vindhyan succession, central India: Time constraints from Pb-Pbisochron ages of its carbonate components Precambrian Research 233 $108-117$

Gregory L C, Meert J G, Pradhan V, Pandit M K, Tamrat E and Malone S J (2006) A paleomagnetic and geochronologic study of the Majhgawan kimberlite, India: Implications for the age of the Upper Vindhyan Supergroup Precambrian Research 149 65-75

Holland T H (1906) Indian Geological Terminology Mem Geol Surv India 6184

Holland H D (2006) The oxygenation of the atmosphere and oceans Philosophical Transactions of the Royal Society B: Biological Sciences 361 903-915

Holmden C, Creaser R A, Muehlenbachs K, Leslie S A and Bergström S M (1998) Isotopic evidence for geochemical decoupling between ancient epeiric seas and bordering oceans: Implications for secular curves Geology 26567 570

Irvine G J, Pearson D G and Carlson R W (2001) Lithospheric mantle evolution of the Kaapvaal Craton: A Re-Os isotope study of peridotite xenoliths from Lesotho kimberlites 
Geophysical Research Letters 28 2505-2508

Kah L C, Lyons T W and Frank T D (2004) Low marine sulphate and protracted oxygenation of the Proterozoic biosphere Nature 431 834-838

Kah L C, Bartley J K and Teal D A (2012) Chemostratigraphy of the Late Mesoproterozoic Atar Group, Taoudeni Basin, Mauritania: Muted isotopic variability, facies correlation, and global isotopic trends Precambrian Research 200203 82-103

Kah L C, Sherman A G, Narbonne G M, Knoll A and Kaufman A J (1999) $\delta^{13} \mathrm{C}$ stratigraphy of the Proterozoic BylotSupergroup, Baffin Island, Canada: Implications for regional lithostratigraphic correlations Canadian Journal of Earth Sciences 36 313-332

Krishnan M S (1943) Geology of India and Burma. Tata McGraw Hill Publication, New Delhi

Konhauser K O, Planavsky N J, Hardisty D S, Robbins L J, Warchola T J, Haugaard R, Lalonde S V, Partin C A, Oonk P B H, Tsikos H, Lyons T W, Bekker A and Johnson C M (2017) Iron formations: A global record of Neoarchaean to Palaeoproterozoic environmental history Earth-Science Reviews 172 140-177

Kumar A, Gopalan K and Rajagopalan G (2001b) Age of the Lower Vindhyan sediments, Central India Current Science 81 806-809

Kumar A, Padma Kumari V M, Dayal A M, Murthy A S N and Gopalan K (1993) Rb-Sr ages of Proterozoic Kimberlites of India: evidence for contemporaneous emplacement Precambrian Research 62 227-237

Kumar S and Srivastava P (1997) A note on the carbonaceous megafossils from the Neoproterozoic Bhander Group, Maihar area, Madhya Pradesh Journal of Paleontological Society of India 42 141-146

Kumar S (1977) Stromatolites and phosphorite in the Tirohan Limestone of Chitrakut area, Satna District, M.P. Current Science 46 341-342

Kumar S (2001a) Mesoproterozoic megafossils Chuaria-Tawuia association may represent part of a multicellular plant, Vindhyan Supergroup, Central India Precambrian Research 106 187-211

Kumar B, Das Sharma S, Sreenivas B, Dayal A M, Rao M N, Dubey N and Chawla B R (2002) Carbon, oxygen and strontium isotope geochemistry of Proterozoic carbonate rocks of the Vindhyan Basin, central India Precambrian Research 113 43-63

Kumar S (2016) Megafossils from the Vindhyan basin, Central India: An overview Journal of the Palaeontological Society of India $\mathbf{6 1} 273-286$

Lyons T W, Reinhard C T and Planavsky N J (2014) The rise of oxygen in Earth's early ocean and atmosphere Nature 506 307-315

Mageswarii G, Pal S, Mishra M and Shrivastava J P (2019) Evidences of felsic volcanism and hydrothermal activities from clays associated with the Palaeoproterozoic Porcellanite Formation of the Vindhyan Supergroup, Central India Geochemistry 79 408-420

Malone S J, Meert J G, Banerjee D M, Pandit M K, Tamrat E, Kamenov G D, Pradhan V R and Sohl L E (2008) Paleomagnetism and Detrital Zircon Geochronology of the Upper Vindhyan Sequence, Son Valley and Rajasthan, India: A ca. 1000Ma Closure age for the Purana Basins Precambrian Research 164 137-159

Mandal B, Vaidya V R, Sen M K, Periyasamy K and Sarkar D (2018) Common Reflection Surface Stack Imaging of the Proterozoic Chambal Valley Vindhyan Basin and Its Boundary Fault in the Northwest India: Constraints on Crustal Evolution and Basin Formation Tectonics 37 13931410

Mandal S, Choudhuri A, Mondal I, Sarkar S, Chakraborty P P and Banerjee S (2019) Revisiting the boundary between the Lower and Upper Vindhyan, Son Valley, India Journal of Earth System Science 128222 https://doi.org/10.1007/ s12040-019-1250-2

McKenzie N R, Hughes N C, Myrow P M, Xiao S and Sharma M (2011) Correlation of Precambrian-Cambrian sedimentary successions across northern India and the utility of isotopic signatures of Himalayan lithotectonic zones Earth and Planetary Science Letters 312 471-483

Miller R G and O'Nions R K (1984) The provenance and crustal residence ages of British sediments in relation to palaeogeographic reconstructions Earth and Planetary Science Letters 68 459-470

Mishra D C (2011) Long hiatus in Proterozoic sedimentation in India: Vindhyan, Cuddapah and Pakhal Basins - A plate tectonic model Journal of the Geological Society of India 77 17-25

Mishra D C (2015) Plume and plate tectonics model for formation of some Proterozoic Basins of India along contemporary mobile belts: Mahakoshal-Bijawar, Vindhyan and Cuddapah Basins Journal of Geological Society of India 85 525-535

Mishra M and Sen S (2017) Petrological study of the early Mesoproterozoic Galucinitc Sandstone and Olive Shale members from the Semri Group, Vindhyan Supergroup in Central India: Implications to input from intrabasinal felsic 
volcanic source and glauconitization Geological Journal DOI: $10.1002 / \mathrm{gj} .29311-20$

Mishra M, Sen S and Kumari K (2017a) Explosive felsic volcanism at Palaeo-Mesoproterozoic boundary from Vindhyan Supergroup, Son Valley, Central India -Evidences of crustal contamination Geochemistry International $\mathbf{5 5}$ 474-488

Mishra M, Srivastava V, Sinha P K and Srivastava H B (2017b) Geochemistry of Mesoproterozoic Deonar Pyroclastics from Vindhyan Supergroup of Central India: Evidences of felsic magmatism in the Son valley Journal of the Geological Society of India 89 375-385

Mishra M, Bickford M E and Basu A (2018) U-Pb age and chemical composition of an ash bed in the Chopan Porcellanite Formation, Vindhyan Supergroup, India The Journal of Geology 126 553-560

Mukherjee A, Bickford M E, Hietpas J, Schieber J and Basu A (2012) Implications of a Newly Dated ca. 1000-Ma Rhyolitic Tuff in the Indravati Basin, Bastar Craton, India The Journal of Geology 120 477-485

Nelson B K and DePaolo D J (1988) Comparison of Isotopic and Petrographic Provenance Indicators in Sediments from Tertiary Continental Basins of New Mexico SEPM Journal of Sedimentary Research 58 348-357

Nie J, Horton B K, Saylor J E, Mora A, Mange M, Garzione C N, Basu A, Moreno C J, Caballero V and Parra M (2012) Integrated provenance analysis of a convergent retroarc foreland system: $\mathrm{U}-\mathrm{Pb}$ ages, heavy minerals, $\mathrm{Nd}$ isotopes, and sandstone compositions of the Middle Magdalena Valley basin, northern Andes, Colombia Earth-Science Reviews 110 111-126

Prasad B (1981) A review of the Vindhyan Supergroup in southeastern Rajsthan Misc Pub Geol Soc India 50 31-40

Prasad B (1984) Geology, sedimentation and paleogeography of the Vindhyan Supergroup, S.E Rajasthan Memoir Geological Survey of India 116148

Prasad B R and Rao V V (2006) Deep seismic reflection study over the Vindhyans of Rajasthan: Implications for geophysical setting of the basin Journal of Earth System Science 115 135-147

Prasad B and Asher R (2016) Record of Ediacaran complex AcanthomorphicAcritarchs from the Lower Vindhyan succession of the Chambal Valley (East Rajasthan), India and their biostratigraphic significance Journal of the Palaeontological Society of India 61 29-60

Rasmussen B, Bose P K, Sarkar S, Banerjee S, Fletcher I R and McNaughton N J (2002) 1.6 Ga U-Pb zircon age for the Chorhat Sandstone, lower Vindhyan, India: Possible implications for early evolution of animals Geology $\mathbf{3 0}$ 103-106

Ray J S, Martin M W, Veizer J and Bowring S A (2002) U-Pb zircon dating and $\mathrm{Sr}$ isotope systematics of the Vindhyan Supergroup, India Geology 30 131-134

Ray J S, Veizer J and Davis W J (2003) C, O, Sr and Pb isotope systematics of carbonate sequences of the Vindhyan Supergroup, India: age, diagenesis, correlations and implications for global events Precambrian Research 121 103-140

Raza M and Casshyap S M (1996) A tectono-sedimentary model of evolution of middle Proterozoic Vindhyan basin Geological Society of India Memoir 36 287-300

Raza M, Casshyap S M and Khan A (2002) Geochemistry of Mesoproterozoic Lower Vindhyan shales from Chittaurgarh, southeastern Rajasthan and its bearing on source rock composition, paleoweathering conditions and tectono-sedimentary environments Journal of Geological Society of India 60 505-518

Raza M, Khan A and Khan M S (2009) Origin of Late Palaeoproterozoic Great Vindhyan basin of North Indian shield: Geochemical evidence from mafic volcanic rocks Journal of Asian Earth Sciences 34 716-730

Raza M, Dayal A M, Khan A, Bhardwaj V R and Rais S (2010) Geochemistry of lower Vindhyan clastic sedimentary rocks of Northwestern Indian shield: Implications for composition and weathering history of Proterozoic continental crust Journal of Asian Earth Sciences 39 5161

Raza M, Khan A, Bhardwaj V R and Rais S (2012) Geochemistry of Mesoproterozoic sedimentary rocks of upper Vindhyan Group, southeastern Rajasthan and implications for weathering history, composition and tectonic setting of continental crust in the northern part of Indian shield Journal of Asian Earth Sciences 48 160-172

Samanta P, Mukhopadhyay S and Eriksson P G (2016) Forced regressive wedge in the Mesoproterozoic Koldaha Shale, Vindhyan basin, Son valley, central India Marine and Petroleum Geology 71 329-343

Sastry M V A and Moitra A K (1984)Vindhyan stratigraphy - A review Mem Geol Surv India (part II) 116 109-148

Sarangi S, Gopalan and Kumar S (2004) Pb-Pb age of earliest megascopic, eukaryotic alga bearing Rohtas Formation, Vindhyan Supergroup, India: implications for Precambrian atmospheric oxygen evolution Precambrian Research 132 107-121

Sarkar S, Eriksson P G and Chakraborty S (2004) Epeiric Sea 
Formation on Neoproterozoic Supercontinent Break-up: ADistinctive Signature in Coastal Storm Bed Amalgamation Gondwana Research 73 13-322

Seilacher A (1998) Triploblastic Animals More Than 1 Billion Years Ago: Trace Fossil Evidence from India Science $\mathbf{2 8 2}$ 80-83

Sen S, Mishra M and Patranabis-Deb S (2014) Petrological study of the Kaimur Group sediments, Vindhyan Supergroup, Central India: implications for provenance and tectonics Geosciences Journal 18 307-324

Sen S and Mishra M (2019) Significance of the tuffaceous beds associated with the Bijaigarh Shale of the Kaimur Group, Vindhyan Supergroup, Central India and their correlation with tuffs in other contemporaneous Proterozoic basins Journal of Earth System Science 128217 https://doi.org/ 10.1007/s12040-019-1212-8

Sengupta S N (1996) The Vindhyan under the north Indian plains Geological Society of India Memoir 36 257-265

Sharma M and Kumar S (2012) Vindhyan basin, Son Valley area, Central India The Palaeontological Society of India (PSIfield guide)

Shields G and Veizer J (2002) Precambrian marine carbonate isotope database: Version 1.1: Carbonate isotope database Geochemistry, Geophysics, Geosystems 3 https://doi.org/ 10.1029/2001GC000266

Shukla A D, George B G and Ray J S (2019) Evolution of the Proterozoic Vindhyan Basin, Rajasthan, India: insights from geochemical provenance of siliciclastic sediments International Geology Review https://doi.org/10.1080/ 00206814.2019.1594412

Singh A K, Chakraborty P P and Sarkar S (2018) Redox structure of Vindhyan hydrosphere: clues from total organic carbon, transition metal (Mo, Cr) concentrations and stable isotope $\left(\delta^{13} \mathrm{C}\right)$ chemistry Current Science 115 1334-1341
Soni M K, Chakraborty S and Jain V K (1987) Vindhyan Supergroup - a review Geological Society of India, Memoir $687-138$

Strauss H (1999) Geological evolution from isotope proxy signals — sulfur Chemical Geology 161 89-101

Sur S, Schieber J and Banerjee S (2006) Petrographic observations suggestive of microbial mats from Rampur Shale and Bijaigarh Shale, Vindhyan basin, India Journal of Earth System Science 115 61-66

Tandon S K, Pant C C and Casshyap S M (1991) Sedimentary basins of India-Tectonic context Gyanodaya Prakashan, Nainital

Tripathy G R and Singh S K (2015) Re-Os depositional age for black shales from the Kaimur Group, Upper Vindhyan, India Chemical Geology 413 63-72

Turner C C, Meert J G, Pandit M K and Kamenov G D (2014) A detrital zircon $\mathrm{U}-\mathrm{Pb}$ and $\mathrm{Hf}$ isotopic transect across the Son Valley sector of the Vindhyan Basin, India: Implications for basin evolution and paleogeography Gondwana Research 26 348-364

Verma A and Shukla U K (2015) Deposition of the Upper Rewa Sandstone Formation of Proterozoic Rewa Group of the Vindhyan Basin, M.P., India: A reappraisal Journal Geological Society of India 86 421-437

Vadlamani R, Hashmi S, Chatterjee C, Ji W-Q and Wu F-Y (2014) Initiation of the intra-cratonicCuddapah basin: Evidence from Paleoproterozoic (1995Ma) anorogenic porphyritic granite in Eastern Dharwar Craton basement Journal of Asian Earth Sciences 79 235-245

Viehmann S, Bau M, Hoffmann J E and Münker C (2015) Geochemistry of the Krivoy Rog Banded Iron Formation, Ukraine, and the impact of peak episodes of increased global magmatic activity on the trace element composition of Precambrian seawater Precambrian Research 270 165180 . 